\title{
Metode Vector Autoregressive (VAR) dalam Menganalisis Pengaruh Kurs Mata Uang Terhadap Ekspor Dan Impor Di Indonesia
}

\author{
Dwi Reskiyani Febrianti*, Muhammad Arif Tiro, \& Sudarmin
}

Program Studi Statistika, Fakultas Matematika dan Ilmu Pengetahuan Alam, Universitas Negeri Makassar, Indonesia

Keywords: VAR, Kurs, Ekspor, Impor.

\begin{abstract}
:
Metode Vector Autoregressive (VAR) adalah salah satu analisis yang digunakan untuk menganalisis data deret waktu. Data deret waktu dikategorikan menurut interval waktu yang sama, baik dalam harian, mingguan, bulanan, kuartalan, ataupun tahunan. Vector Autoregressive (VAR) merupakan pemodelan yang tidak perlu menentukan variabel endogen dan variabel eksogen. Tujuan dari penelitian ini adalah untuk mengetahui pengaruh kurs mata uang terhadap ekspor dan impor di Indonesia. Data yang digunakan dalam penelitian ini adalah data kurs, ekspor, dan impor dari bulan Januari 2014 hingga Desember 2018. Uji stasioneritas dalam penelitian ini menggunakan metode Augmented Dickey Fuller (ADF). Dalam penelitian ini menggunakan differencing terhadap data karena data tidak stasioner pada level. Penentuan panjang lag optimal diperoleh dari nilai Akaike Information Criterion (AIC) yang paling minimum. Estimasi model VAR diperoleh setelah penentuan panjang lag optimal. Uji kausalitas dilakukan dengan uji Causality Granger untuk melihat pengaruh timbal balik antar variabel yang diuji dalam penelitian ini. Terakhir menggunakan uji Impulse Response Function (IRF) untuk menelusuri guncangan atau shock suatu variabel terhadap variabel lainnya. Adapun hasil analisis yang diperoleh menunjukkan terdapat dua hubungan satu arah yaitu kurs mempengaruhi ekspor dan ekspor mempengaruhi impor.
\end{abstract}

\section{Pendahuluan}

Nilai tukar atau kurs merupakan suatu harga relatif yang diartikan sebagai nilai dari suatu mata uang terhadap mata uang lainnya. Hal tersebut menentukan daya beli paling tidak untuk barang yang diperdagangkan dari satu nilai mata uang terhadap nilai mata uang lainnya. Perubahan nilai tukar berpengaruh nyata terhadap harga barang yang diperdagangkan. Apresiasi nilai tukar dalam suatu negara akan menurunkan harga barang ekspornya dan menaikkan harga barang impor bagi partner dagang mereka (Aninditha dan Reed, 2008). Ekspor adalah upaya untuk melakukan penjualan komoditi yang kita miliki kepada negara lain atau bangsa asing sesuai dengan peraturan pemerintah dengan mengharapkan pembayaran dalam valuta asing, serta melakukan komunikasi dengan bahasa asing (Amir, 2001). Sedangkan impor merupakan pembelian atau pemasukan barang dari luar negeri ke dalam suatu perekonomian dalam negeri (Sukirno, 2006). Perdagangan internasional (ekspor dan impor) akan menimbulkan perbedaan mata uang yang digunakan antar negara-negara yang bersangkutan. Akibatnya adanya perbedaan mata uang antar negara ekspotir dan impotir menimbulkan suatu perbedaan nilai tukar mata uang atau kurs (Pridayanti, 2014).

Apresiasi nilai tukar akan memberi dampak harga produk impor menjadi lebih murah dibandingkan harga sebelum terjadinya apresiasi. Sebaliknya, pada saat terjadi depresiasi nilai tukar, permintaan barang ekspor akan meningkat akibat dari harga barang ekspor yang lebih rendah. Sedangkan permintaan akan barang impor menjadi menurun

\footnotetext{
* Corresponding author.

E-mail address: febypettaduppa13@gmail.com
} 
karena depresiasi nilai tukar menyebabkan harga barang impor menjadi lebih tinggi. Secara simultan, perubahan neraca perdagangan akan mempengaruhi nilai tukar mata uang dalam negeri akibat dari transaksi ekspor dan impor yang menyebabkan keluar masuknya mata uang (Firdaus dkk, 2018).

Menurut John E. Hanke (2005), sekumpulan data hasil observasi secara teratur dari waktu ke waktu disebut data deret berkala atau Time Series. Data kurs mata uang dan data ekspor serta data impor merupakan data time series yang bertipe diskrit yang menunjukkan fenomena atau aktivitas pada waktu tertentu. Untuk melihat seberapa besar pengaruh kurs mata uang terhadap ekspor dan impor di Indonesia, maka digunakan metode Vector Autoregressive (VAR).

Model VAR pertama kali diperkenalkan oleh C.A. Sims (1972) sebagai pengembangan dari pemikiran Granger (1969). Granger menyatakan bahwa apabila dua variabel misalkan $x$ dan $y$ memiliki hubungan kusual di mana $\mathrm{x}$ mempengaruhi y maka informasi masa lalu $x$ dapat membantu memprediksi $y$. Salah satu keunggulan model VAR yaitu sederhana dimana peneliti tidak perlu menentukan mana variabel endogen dan mana variabel eksogen (Gujarati, 1995). Maka dari itu, peneliti tertarik untuk mencari tahu pengaruh kurs mata uang terhadap ekspor dan impor di Indonesia dengan menggunakan metode Vector Autoregressive (VAR).

\section{Tinjauan Pustaka}

\subsection{Kurs Mata Uang}

Nilai tukar atau kurs mata uang didefinisikan sebagai harga dari mata uang asing dalam mata uang domestik, sehingga peningkatan nilai tukar berarti meningkatnya harga dari valuta asing yang menyebabkan mata uang domestik relatif murah atau terjadi depresiasi, sebaliknya jika terjadi penurunan jumlah unit mata uang domestik yang diperlukan untuk membeli suatu unit valuta asing, berarti terjadi peningkatan relatif nilai mata uang domestik atau terjadi apresiasi (Firdaus dkk, 2018). Nilai tukar mata uang suatu negara dibedakan atas nilai tukar nominal dan nilai tukar riil. Nilai tukar nominal merupakan harga relatif mata uang dua negara (Mankiw, 2003). Misalnya, USD 1 bernilai seharga $\mathrm{Rp} 9.500$,- di pasar uang. Sedangkan nilai tukar riil menyatakan tingkat, dimana pelaku ekonomi dapat memperdagangkan barang-barang dari suatu negara untuk barang-barang dari negara lain. Perubahan nilai tukar dapat mengubah harga relatif suatu produk menjadi lebih mahal atau lebih murah, sehingga nilai tukar terkadang digunakan sebagai alat untuk meningkatkan daya saing (Ginting, 2013).

\subsection{Ekspor dan Impor}

Ekspor adalah pembelian negara lain atas barang buatan perusahaan-perusahaan di dalam negeri. Faktor terpenting yang menentukan ekspor adalah kemampuan dari negara tersebut untuk mengeluarkan barang-barang yang dapat bersaing dalam pasaran luar negeri (Sukirno, 2008). Ekspor akan secara langsung mempengaruhi pendapatan nasional. Akan tetapi, hubungan yang sebaliknya tidak selalu berlaku, yaitu kenaikan pendapatan nasional belum tentu menaikkan ekspor oleh karena pendapatan nasional dapat mengalami kenaikan sebagai akibat dari kenaikan pengeluaran rumah tangga, investasi perusahaan, pengeluaran pemerintah, dan penggantian barang impor dengan barang buatan dalam negeri (Sukirno, 2008). "Exports are domestically produced goods and services that are abroad", ekspor mempunyai peran strategis, terlebih dalam memberikan kontribusi terhadap pembangunan ekonomi suatu negara dan cadangan devisa negara (Mankiw, 2012). Ketika nilai ekspor meningkat, dapat diartikan permintaan barang dari negara lain mengalami peningkatan. Jika ekspor menurun sebaliknya dapat diartikan permintaan negara lain terhadap barang ekspor mengalami pelemahan. Ekspor merupakan injeksi masuknya aliran pendapatan seperti halnya investasi.

Berbeda dengan ekspor yang akan menyumbangkan pendapatan bagi negara, impor merupakan pengeluaran negara. Impor dapat diartikan sebagai pembelian barang dan jasa dari luar negeri ke dalam negeri dengan perjanjian kerjasama antara 2 negara atau lebih. Impor juga bisa dikatakan sebagai perdagangan dengan cara memasukkan barang dari luar negeri ke wilayah Indonesia dengan memenuhi ketentuan yang berlaku (Hutabarat, 1996). Impor adalah bagian penting dari perdagangan internasional. Suatu negara tidak dapat memenuhi kebutuhan barang dan jasa itu sendiri karena berbagai faktor, maka dari itu suatu negara melakukan kegiatan impor untuk memenuhi kebutuhankebutuhan tertentu. 


\subsection{Deret Waktu}

Deret waktu (Time Series) adalah serangkaian nilai pengamatan (observasi) yang diambil selama kurun waktu tertentu, pada umumnya dalam interval-interval yang sama panjang. Deret waktu menampakkan sejumlah pergerakan tertentu atau variasi yang khas. Analisis pergerakan khas deret waktu dianggap penting dalam berbagai hal, salah satunya adalah untuk tujuan proyeksi pergerakan variabel di masa mendatang (Makridakis, 1999). Data deret waktu merupakan kumpulan nilai observasi peubah pada waktu-waktu yang berbeda. Data deret waktu dikategorikan menurut interval waktu yang sama, baik dalam harian, mingguan, bulanan, kuartalan, ataupun tahunan (Gujarati, 2003). Tujuan analisis deret waktu adalah untuk mendapatkan suatu ukuran yang dapat digunakan untuk membuat keputusan masa kini, untuk prediksi atau peramalan beberapa periode kedepan, dan untuk perencanaan operasional di masa yang akan datang (Clark dan Schkade, 1983).

\subsection{Uji Stasioneritas}

Uji stasioneritas dapat dideteksi secara formal menggunakan uji Augmented Dickey-Fuller (ADF). Uji ini melihat apakah terdapat unit root di dalam model atau tidak. Unit root dapat pula dipandang sebagai uji stasioneritas. Hal ini karena pada prinsipnya uji tersebut dimaksudkan untuk menguji apakah koefisien tertentu dalam model autoregressive yang ditaksir mempunyai nilai 1 atau tidak. Statistik uji pada uji stasioneritas dapat dihitung dengan menggunakan ADF hitung. Uji ADF dilakukan dengan tahap pengujian hipotesis sebagai berikut:

Hipotesis:

$\mathrm{H}_{0}: \phi=1$

$\mathrm{H}_{1}:|\phi|<1$

(terdapat unit root atau data tidak stasioner)

Statistik uji:

(tidak terdapat unit root atau data stasioner)

$$
\mathrm{ADF}_{\text {hitung }}=\frac{\widehat{\phi}-1}{S E(\widehat{\phi})}
$$

Dengan

$S E(\hat{\phi})=\left[\hat{\sigma}_{e}^{2}\left(\sum_{t=1}^{n} Y_{t-1}^{2}\right)\right]^{1 / 2}$

$\hat{\sigma}_{e}^{2}=\sum_{t=1}^{n} \frac{\left(Y_{t}-\widehat{\phi} Y_{t-1}\right)^{2}}{(n-1)}$

$t=1, \ldots, n \quad Y_{0}=0$.

$\mathrm{H}_{0}$ ditolak jika nilai statistik uji ADF hitung kurang dari nilai tabel Critical Value ADF 5\% atau nilai probabilitas ADF lebih kecil dari nilai residual pada output. Jika $\mathrm{H}_{0}$ ditolak, maka data stasioner.

\subsection{Vector Autoregressive (VAR)}

Metode Vector Autoregressive (VAR) menurut Gujarati (2012) merupakan pemodelan persamaan simultan yang memiliki beberapa variabel endogen secara bersamaan, namun masing-masing variabel endogen dijelaskan oleh lag dari nilainya sendiri dan variabel endogen lainnya dalam model. Model VAR digunakan jika data stasioner pada level. Menurut Gujarati (2003), analisis VAR memiliki beberapa keunggulan antara lain:

1) Tidak perlu membedakan antara peubah bebas dan peubah terikat

2) Menggunakan metode Ordinary Least Square (OLS) dalam mengestimasi tiap persamaan

3) Peramalan dengan menggunakan metode VAR dalam beberapa kasus lebih baik dibandingkan persamaan simultan yang kompleks.

Secara umum model Vector Autoregressive (VAR) dapat diformulasikan sebagai berikut:

dimana

$$
x_{t}=\mathrm{A}_{0}+\mathrm{A}_{1} x_{t-1}+\mathrm{A}_{2} x_{t-2}+\mathrm{A}_{3} x_{t-3}+\cdots+\mathrm{A}_{p} x_{t-p}+e_{t}
$$

$x_{t}=$ vektor berukuran $\mathrm{nx} 1$ yang berisi $\mathrm{n}$ peubah dalam model VAR

$\mathrm{A}_{0} \quad=$ vektor intersep berukuran $\mathrm{nx} 1$

$\mathrm{A}_{1} \quad=$ matriks koefisien berukuran $\mathrm{nxn}$ 
$e_{t} \quad=$ vektor sisaan berukuran $\mathrm{nx} 1$

\subsection{Penentuan Panjang Lag Optimal}

Pemeriksaan lag digunakan untuk menentukan panjang lag optimal yang akan digunakan dalam analisis selanjutnya dan akan menemukan estimasi parameter untuk model Vector Autoregressive (VAR). Dalam model VAR, panjang lag menunjukkan derajat bebas. Model terbaik adalah model yang memiliki nilai Akaike Information Criterion (AIC) terkecil. Kriteria tersebut dirumuskan sebagai berikut:

$$
A I C(k)=T \ln \left(\frac{\operatorname{SSR}(k)}{T}\right)+2 n
$$

Dengan:

$\mathrm{T} \quad=$ Jumlah observasi yang digunakan

$\mathrm{k} \quad=$ Panjang lag

SSR = Residual Sum of Square (Jumlah kuadrat residual)

$\mathrm{n} \quad=$ Jumlah parameter yang diestimasi

\subsection{Uji Kausalitas}

Uji kausalitas adalah pengujian untuk menentukan hubungan sebab akibat antara variabel dalam sistem Vector Autoregressive (VAR). Uji kausalitas pada permodelan VAR bertujuan untuk melihat pengaruh antar peubah baik jangka panjang maupun jangka pendek. Adanya hubungan antar peubah tidak membuktikan adanya kausalitas atau pengaruh sehingga untuk mengetahui apakah terdapat pengaruh satu arah maupun dua arah perlu dilakukan uji kausalitas. Jika sebuah kejadian x terjadi sebelum y, maka terdapat kemungkinan bahwa x mempengaruhi y namun tidak mungkin sebaliknya, inilah ide dalam penerapan Uji kausalitas Granger (Gujarati, 2003).

Untuk melakukan pengujian terhadap hipotesis digunakan uji $\mathrm{F}$ dengan tahapan hipotesis sebagai berikut:

Hipotesis:

$\mathrm{H}_{0}: \theta_{1 p}$ atau $\gamma_{2 p}=0$ (variabel $\theta$ tidak berpengaruh terhadap variabel $\gamma$ dan sebaliknya)

$\mathrm{H}_{1}: \theta_{1 p}$ atau $\gamma_{2 p} \neq 0$ (variabel $\theta$ berpengaruh terhadap $\gamma$ dan sebaliknya)

Statistik uji:

dengan

$$
\mathrm{F}=\frac{\left(R S S_{R}-R S S_{U R}\right) / p}{R S S_{U R} /(n-b)}
$$

$R S S_{R} \quad=$ Residual sum of square dari regresi bersyarat (restricted)

$R S S_{U R} \quad=$ Residual sum of square dari regresi tanpa syarat (unrestricted)

$p \quad$ = banyak lag

$n \quad=$ banyak data pengamatan

$b \quad=$ banyak parameter yang diestimasi pada model

\subsection{Impulse Response Function (IRF)}

Structural Impulse Response Function digunakan untuk menggambarkan bagaimana shock yang diterima variabel baik dari variabel itu sendiri maupun dari variabel lain. Uji IRF juga bertujuan untuk melihat berapa lama shock yang diterima suatu variabel (Batubara \& Saskara, 2013). Perhitungan IRF sebagai berikut:

dengan:

$$
\operatorname{IRF}(h)=\Gamma^{h}
$$

$\Gamma \quad=$ matriks parameter dari model VAR

$\mathrm{h} \quad=$ periode peramalan

C = cholesky decomposition matriks dari matriks varian kovarian shock 


\section{Metode Penelitian}

\subsection{Sumber Data}

Data yang digunakan dalam penelitian ini yaitu data kurs mata uang, data ekspor, dan data impor di Indonesia. Data tersebut adalah data sekunder yang diperoleh dari Situs Kementerian Perdagangan Republik Indonesia dan Badan Pusat Statistik. Sampel data yang diambil selama 60 bulan dari bulan Januari 2014 hingga Desember 2018.

\subsection{Definisi Operasional Peubah}

Definisi dari variabel-variabel yang digunakan dalam penelitian ini adalah:

1. Kurs mata uang adalah nilai tukar dari suatu mata uang terhadap mata uang lainnya

2. Ekspor menurut Statistik Perdagangan Indonesia yaitu perdagangan dengan cara mengeluarkan barang dari dalam keluar wilayah Pabean Indonesia dengan memenuhi ketentuan yang berlaku

3. Impor adalah perdagangan dengan cara memasukkan barang dari luar negeri ke dalam Pabean Indonesia dengan mematuhi ketentuan peraturan perundang-undangan yang berlaku (Tandjung, 2011).

\subsection{Teknik Analisis}

Dalam penelitian ini, teknik analisis data terdiri dari:

1. Uji kondisi stasioneritas variabel. Menguji kestasioneran masing-masing variabel dengan perbandingan nilai Augmented Dickey-Fuller dengan nilai error $(0,05)$

2. Jika data tidak stasioner dilakukan differencing, sehingga stasioner terpenuhi adalah stasioner differencing

3. Menentukan nilai Akaike Information Criterion (AIC) terhadap beberapa lag yang telah dicobakan

4. Penentuan orde VAR berdasarkan nilai AIC terkecil dari beberapa lag yang telah dicobakan

5. Analisis model VAR

6. Uji dan analisis kausalitas Granger

7. Uji Impulse Response Function (IRF).

\section{Hasil dan Pembahasan}

\subsection{Uji Stasioner}

Tabel 1. Uji Augmented Dickey Fuller

\begin{tabular}{lccc}
\hline \multirow{2}{*}{ Variabel } & Level & 1st difference & 2st difference \\
\cline { 2 - 4 } & Prob. & Prob. & Prob. \\
\hline Kurs & 0,65 & $<0,01$ & - \\
Ekspor & 0,59 & $<0,01$ & - \\
Impor & 0,84 & 0,24 & 0,01 \\
\hline
\end{tabular}

Dari Tabel 1 diperoleh uji ADF dengan membandingkan nilai probabilitas pada tabel MacKinnon. Hasil Uji ADF terhadap variabel pada tingkat level menunjukkan bahwa tiga variabel belum ada yang stasioner. Hal ini ditunjukkan oleh nilai probabilitas yang lebih besar dari $\alpha(5 \%)$. Kemudian dilakukan uji ADF pada turunan pertama terhadap tiga variabel tersebut. Hasil yang diperoleh pada tingkat turunan pertama menunjukkan bahwa variabel kurs dan variabel ekspor bersifat stasioner tetapi variabel impor belum stasioner. Selanjutnya, dilakukan uji ADF pada turunan Kedua. Hasil pengujian yang diperoleh menunjukkan bahwa variabel impor bersifat stasioner.

\subsection{Uji Lag Optimal}

Panjang lag yang diikutsertakan dalam pengujian ini adalah nilai dari lag 0 sampai dengan lag 3 karena sudah tidak memiliki nilai modulus yang lebih dari 1 sehingga sampai lag 3 model masih stabil. 
Tabel 2. Uji lag optimum

\begin{tabular}{cc}
\hline Lag & AIC \\
\hline 0 & $-6,80$ \\
1 & $-9,15$ \\
2 & $-9,62$ \\
3 & $-9,77^{*}$ \\
\hline
\end{tabular}

*lag optimum

Berdasarkan Tabel 2, Kriteria yang menunjukkan lag optimum berada pada lag 3 yang memiliki nilai AIC terkecil. Sehingga model yang akan kita gunakan untuk uji kausalitas dan analisis model VAR adalah pada lag 3.

\subsection{Analisis Model VAR}

Diperoleh persamaan estimasi model Vector Autoregressive (VAR) sebagai berikut:

$$
\begin{aligned}
& \Delta y_{1 t}=0,14 \Delta y_{1_{t-1}}+0,11 \Delta y_{2_{t-1}}-0,03 \Delta y_{3_{t-1}}-0,73 \\
& \Delta y_{2 t}=0,89 \Delta y_{1_{t-1}}+0,02 \Delta y_{2_{t-1}}+0,18 \Delta y_{3_{t-1}}+0,97 \\
& \Delta y_{3 t}=1,34 \Delta y_{1_{t-1}}-0,25 \Delta y_{2_{t-1}}+0,58 \Delta y_{3_{t-1}}-7,48
\end{aligned}
$$

Dari persamaan dan hasil yang diperoleh bahwa variabel bebas pada persamaan VAR yaitu $\Delta y_{1 t}$ (kurs), $\Delta y_{2 t}$ (ekspor), dan $\Delta y_{3 t}$ (impor) secara berturut-turut menjelaskan keberagaman ( $R$-squared) kurs mata uang sebesar $90,25 \%$, ekspor sebesar $65,42 \%$, dan impor sebesar 68,34\%. Dari hasil persamaan tersebut terlihat bahwa pada lag 3:

1. Kurs berpengaruh secara signifikan terhadap ekspor tetapi berkontribusi kecil terhadap impor

2. Ekspor berpengaruh secara signifikan terhadap kurs dan impor

3. Impor berpengaruh secara signifikan terhadap kurs tetapi berkontribusi kecil terhadap ekspor.

\subsection{Uji Kausalitas}

Tabel 3. Pengujian kausalitas granger

\begin{tabular}{lccc}
\hline$H_{0}$ & $F_{\text {hitung }}$ & $P$-value & Ket \\
\hline$y_{3}$ bukan penyebab granger $y_{2}$ & 0,97 & 0,41 & Gagal tolak $\mathrm{H}_{0}$ \\
$y_{2}$ bukan penyebab granger $y_{3}$ & 2,98 & 0,04 & Tolak $\mathrm{H}_{0}$ \\
\hline$y_{1}$ bukan penyebab granger $y_{2}$ & 3,30 & 0,03 & Tolak $\mathrm{H}_{0}$ \\
$y_{2}$ bukan penyebab granger $y_{1}$ & 1,34 & 0,27 & Gagal tolak $\mathrm{H}_{0}$ \\
\hline$y_{1}$ bukan penyebab granger $y_{3}$ & 1,65 & 0,19 & Gagal tolak $\mathrm{H}_{0}$ \\
$y_{3}$ bukan penyebab granger $y_{1}$ & 0,93 & 0,43 & Gagal tolak $\mathrm{H}_{0}$ \\
\hline
\end{tabular}

Hasil uji kausalitas Granger dengan variabel $y_{1}$ adalah kurs, $y_{2}$ adalah ekspor, dan $y_{3}$ adalah impor menunjukkan bahwa terdapat 2 hubungan satu arah. Nilai $p$-value $<0,05$ yang berarti tolak $\mathrm{H}_{0}$ yaitu hubungan satu arah Ekspor mempengaruhi Impor dengan nilai p-value 0,04 dan Kurs mempengaruhi Ekspor dengan nilai p-value 0,03.

\subsection{Impulse Response Function (IRF)}

Berdasarkan Gambar 1, analisis IRF selama 10 periode untuk respon variabel ekspor terhadap variable impor, pada periode pertama merespon negatif terhadap shock atau guncangan dan terus menurun hingga periode ketiga dan pada periode keempat guncangan mulai berkurang dan terjadi peningkatan dan merespon positif. Kemudian pada periode 
kelima kembali menurun dan bernilai negatif hingga pada periode kesepuluh. Untuk respon variabel ekspor terhadap variabel kurs pada periode pertama sampai periode kelima mengalami fluktuatif yaitu merespon positif dan negatif (naik-turun) terhadap guncangan. Kemudian pada periode kelima sampai periode kesepuluh fluktuasi mulai mengecil artinya ekspor tidak lagi sangat bergejolak dan mulai stabil terhadap kurs. Sedangkan respon terhadap dirinya sendiri cukup tinggi dan bernilai postif dari periode pertama hingga periode kesepuluh.

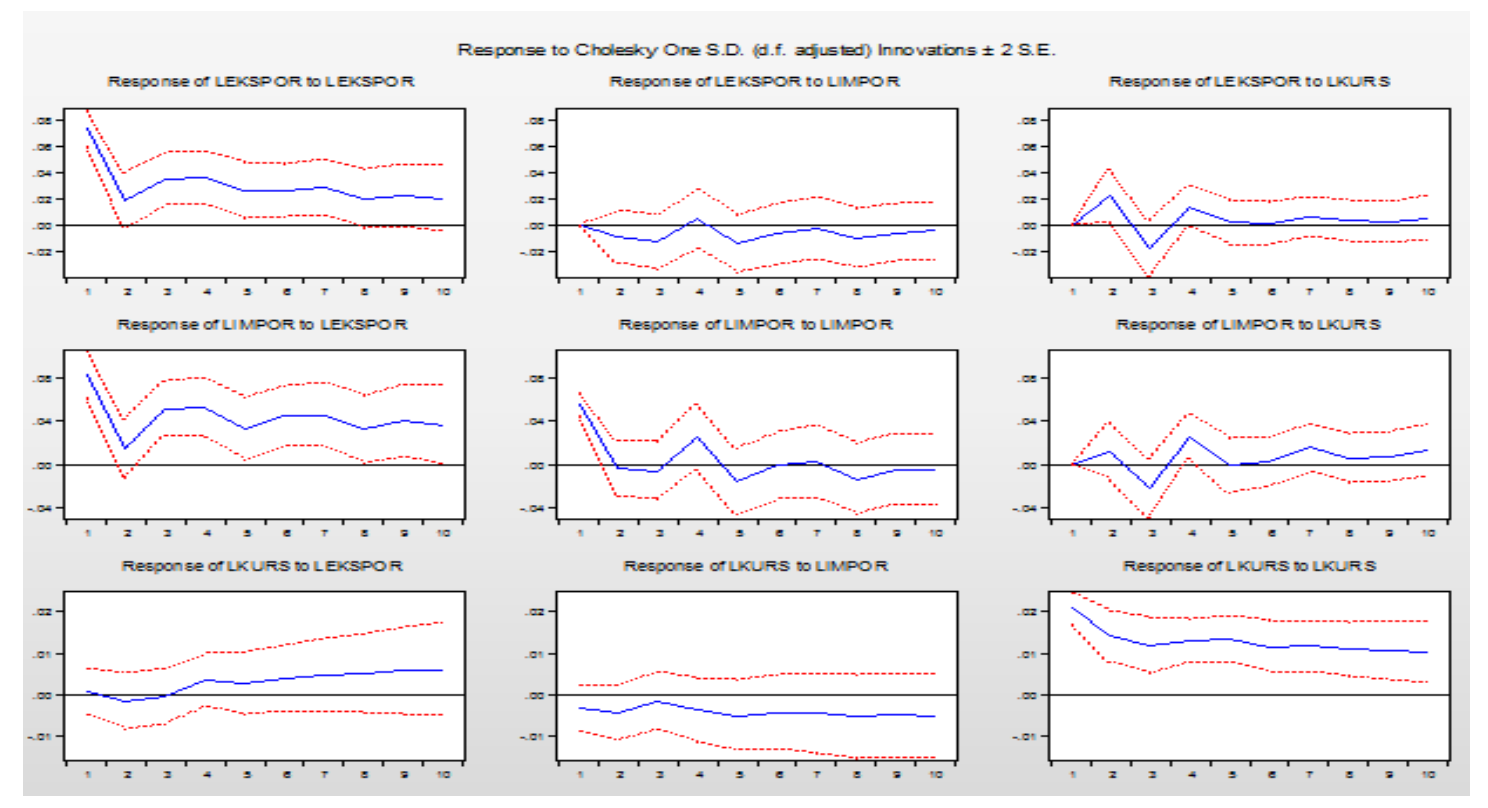

Gambar 4.1. Plot Impulse Response Function

Respon variabel impor terhadap variabel ekspor dari awal periode hingga periode kesepuluh mengalami guncangan ke atas dan terus merespon positif. Kemudian respon terhadap variabel kurs pada periode pertama hingga periode kelima mengalami fluktuatif terhadap guncangan. Pada periode keenam hingga periode kesepuluh respon variabel impor terhadap variabel kurs bernilai positif. Sedangkan untuk respon terhadap dirinya pada periode pertama hingga periode keenam mengalami fluktuatif terhadap guncangan. Kemudian pada periode keenam hingga periode ketujuh fluktuasi mulai mengecil dan pada periode kedelapan hingga periode kesepuluh mengalami guncangan dan menurun yang bernilai negatif.

Untuk respon variabel kurs terhadap variabel ekspor pada awal periode sampai periode ketiga, kurs merespon negatif saat terjadi shock atau guncangan terhadap ekspor kemudian merespon positif pada periode keempat dan terus meningkat sampai periode kesepuluh. Kemudian respon terhadap variabel impor dari awal periode sampai periode kesepuluh, kurs merespon negatif saat terjadi shock atau guncangan. Sedangkan respon terhadap dirinya pada periode pertama hingga periode kesepuluh terus merespon positif.

\section{Kesimpulan}

Berdasarkan hasil penelitian dan pembahasan yang telah dibahas, maka dapat disimpulkan:

1. Dari estimasi model VAR diperoleh tiga estimasi model yaitu:

$$
\begin{aligned}
& \Delta y_{1 t}=0.14 \Delta y_{1_{t-1}}+0.11 \Delta y_{2_{t-1}}-0.03 \Delta y_{3_{t-1}}-0.73 \\
& \Delta y_{2 t}=0.89 \Delta y_{1_{t-1}}+0.02 \Delta y_{2_{t-1}}+0.18 \Delta y_{3_{t-1}}+0.97 \\
& \Delta y_{3 t}=1.34 \Delta y_{1_{t-1}}-0.25 \Delta y_{2_{t-1}}+0.58 \Delta y_{3_{t-1}}-7.48
\end{aligned}
$$

Dari hasil persamaan tersebut terlihat bahwa:

1. Kurs berpengaruh secara signifikan terhadap ekspor tetapi berkontribusi kecil terhadap impor

2. Ekspor berpengaruh secara signifikan terhadap kurs dan impor

3. Impor berpengaruh secara signifikan terhadap kurs tetapi berkontribusi kecil terhadap ekspor. 
2. Uji granger causality menunjukkan bahwa dari ketiga variabel yang diteliti yaitu kurs mata uang, ekspor, dan impor terdapat dua hubungan satu arah (unindirectional) yaitu kurs mempengaruhi ekspor tetapi tidak sebaliknya, dan ekspor mempengaruhi impor tetapi tidak juga sebaliknya.

\section{References}

Amir, M. (2001). Ekspor Impor Teori \& Penerapannya. Jakarta: PPM.

Anindita, R., \& Reed, M. R. (2008). Bisnis dan Perdagangan Internasional. Yogyakarta: CV. Andi Offset.

Badan Pusat Statistik. (t.thn.). Diambil kembali dari Badan Pusat Statistik: www.bps.go.id

Batubara, D. M., \& Saskara, I. N. (2013). Analisis Hubungan Ekspor, Impor, PDB, dan Utang Luar Negeri Indonesia Periode 1970-2013. 46-55.

Clark, J., \& Schkade. (1983). Statistical Analysis for Administrative Decisions. USA: Ohio South-Western Publishing CO.

Firdaus, M., Holis, A., Amaliah, S., Fazri, M., \& Sangadji, M. (2018). Dampak Pergerakan Nilai Tukar Rupiah Terhadap Aktivitas Ekspor dan Impor Nasional.

Ginting, A. (2013). Pengaruh Nilai Tukar Terhadap Ekspor Indonesia. Buletin Ilmiah Litbang Perdagangan.

Granger, C. (1969). Investigating Causal Relations by Econometric Models and Cross-spectral Methods. The Econometric Society, 424-438.

Gujarati, D. N. (2003). Basic Econometrics Fourth Edition. New York: Gary Burke.

Hadiyatullah. (2011). Model Vector Autoregressive (VAR) dan Penerapannya untuk Analisis Pengaruh Harga Migas Terhadap Indeks Harga Konsumen (IHK) (Studi Kasus Daerah Istimewa Yogyakarta, Periode 1997-2009). Skripsi.

Hanke, J., \& Wichern, D. (2005). Business Forecasting. Pearson.

Hutabarat, R. (1996). Transaksi Ekspor Impor. Jakarta: Erlangga.

Juliodinata, A. I. (2017). Metode Vector Autoregressive dalam Menganalisis Pengaruh Kurs Mata Uang, Inflasi, dan Suku Bunga Terhadap Indeks Harga Saham Gabungan. Skripsi.

Kementerian Perdagangan Republik Indonesia. (t.thn.). Diambil kembali dari Kementerian Perdagangan Republik Indonesia: kemendag.go.id

Makridakis. (1999). Metode dan Aplikasi Peramalan. Jakarta: Binarupa Aksara.

Mankiw, G. (2003). Macroeconomics 5th Edition. New York: Worth Publishers.

Pridayanti, A. (2014). Pengaruh Ekspor, Impor, dan Nilai Tukar Terhadap Pertumbuhan Ekonomi di Indonesia Periode 2002-2012.

Sims, C. A. (1980). Macroeconomics and Reality. Econometrica, 1-48.

Sukirno, S. (2006). Pengantar Teori Makro Ekonomi. Jakarta: PT Raja Grafindo Persada.

Sukirno, S. (2008). Makro Ekonomi Teori Pengantar. Jakarta: PT. Raja Grafindo Persada.

Tandjung, M. (2011). Aspek dan Prosedur Ekspor - Impor. Jakarta: Salemba Empat. 